\title{
A Contribution of Beef to Human Health: A Review of the Role of the Animal Production Systems
}

\author{
Dario Pighin, ${ }^{1,2,3}$ Adriana Pazos, ${ }^{1,3}$ Verónica Chamorro, ${ }^{1}$ \\ Fernanda Paschetta, ${ }^{1}$ Sebastián Cunzolo, ${ }^{1,3}$ Fernanda Godoy, ${ }^{1}$ Valeria Messina, ${ }^{2,4}$ \\ Anibal Pordomingo, ${ }^{5}$ and Gabriela Grigioni ${ }^{1,2,3}$ \\ ${ }^{1}$ Food Technology Institute-INTA, Morón, B1708WAB Buenos Aires, Argentina \\ ${ }^{2}$ The National Council for Scientific and Technical Research (CONICET), Rivadavia 1917, C1033AAJ Buenos Aires, Argentina \\ ${ }^{3}$ Morón University, Cabildo 134, Morón, B1708JPD Buenos Aires, Argentina \\ ${ }^{4}$ CINSO-CITEDEF, UNIDEF (Strategic I \& D for Defense), CONICET-Ministry of Defense, Juan Bautista de la Salle 4970, \\ Villa Martelli, B1603ALO Buenos Aires, Argentina \\ ${ }^{5}$ Experimental Station INTA Anguil, National Route, No. 5, Km. 580, 6326 La Pampa, Argentina
}

Correspondence should be addressed to Dario Pighin; pighin.dario@inta.gob.ar

Received 25 September 2015; Revised 11 December 2015; Accepted 24 December 2015

Academic Editor: Rosaria Marino

Copyright (C) 2016 Dario Pighin et al. This is an open access article distributed under the Creative Commons Attribution License, which permits unrestricted use, distribution, and reproduction in any medium, provided the original work is properly cited.

\begin{abstract}
Meat and meat products constitute important source of protein, fat, and several functional compounds. Although beef consumption may implicate possible negative impacts on human health, its consumption can also contribute to human health. Quality traits of beef, as well as its nutritional properties, depend on animal genetics, feeding, livestock practices, and post mortem procedures. Available data show that emerging beef production systems are able to improve both, quality and nutritional traits of beef in a sustainable way. In this context, Argentina's actions are aimed at maximising beef beneficial effects and minimising its negative impact on human health, in a way of contributing to global food security.
\end{abstract}

\section{Introduction}

Meat is an important part of human diet with strong implications in health, economy, and culture worldwide. Meat production involves numerous domestic species, depending on many factors like religious and cultural beliefs, convenience, availability, and so forth [1].

It is well established that meat has several key nutritional factors, like lipids, proteins with high biological value, trace elements, and vitamins $[2,3]$. Meat quality intrinsic characteristics such as colour, flavour, tenderness, texture, juiciness, and odour as well as its nutritional properties depend on animal genetics, feeding, and livestock practices and on the post mortem processes that take place during the conversion of muscle into meat [4].

Due to the stated reasons, beef consumption as part of balanced diets in developing regions will promote nutrition security. Thomas et al. [5] stated the importance of animal agriculture not only for the production of high quality proteins but also for sustaining rural livelihoods and possibly contributing to food security. Nevertheless, it is important to remark that since energy and protein transformation efficiency in ruminants is very low, food security can be effectively promoted only if feeds given to the animals are not in competition with humans.

The World Food Summit of 1996 defined food security as existing "when all people at all times have access to sufficient, safe, nutritious food to maintain a healthy and active life." Commonly, the concept of food security is defined as including both physical and economic access to food that meets people's dietary needs as well as their food preferences. Food security is a complex sustainable development issue, linked to health through malnutrition, but also to sustainable economic development, environment, and trade.

Food and Agriculture Organization (FAO) pointed out that the quality of diets has also been improved. In developing 
regions, several improvements were observed over the last two decades. For example, per capita availability of fruits and vegetables, livestock products, and vegetable oils increased by 90,70 , and 32 percent since 1990-92, respectively. A $20 \%$ increase in protein availability per person was also noted. FAO stated that these enhancements were not fully seen in Africa or Southern Asia. In these regions, diets remain imbalanced and heavily dependent on cereals and roots and tubers. These monotonous diets often comprised negligible quantities of meat, fish, or ascorbic acid. As a consequence, they typically contained a preponderance of foods that inhibit ferric absorption. It should be emphasized that absorption of micronutrients is strongly influenced by the combination of foods eaten in a given meal [6]. Moreover, increasing fat content of diets often facilitates absorption of provitamin A, carotenoids, and vitamin A.

Meat consumption may also represent some risks to human health. Depending on several factors, many reports warn against its metabolic deleterious effects specially linked to cholesterol saturated fatty acids (SFA) levels. Low polyunsaturated fatty acids (PUFA) levels, or inappropriate SFA/PUFA or PUFA n-6/PUFA n-3, had been represented as an inconvenient in usual meat consumption.

Also, fresh meat is a highly perishable product due to its biological composition. Several factors such as storage temperature, packing conditions, endogenous enzymes, moisture, light, and microorganisms can affect shelf life and freshness. In this sense, meat processing and preservations technologies play essential roles in food security, in order to supply the expanding populations with sufficient quantities of good-quality and affordable meat products.

Several authors have reported methods and technologies to be applied in fresh meat with the aim of extending meat shelf life [7]. One of the common processes used in meat preservation is concerned with inhibiting microbial spoilage, and applying these methods deteriorative changes such as colour and oxidative process should be minimized [8]. Zhou and coauthors [7] presented an extended review comprising current methods and technologies for fresh meat preservation, their applications, and implications for extending meat shelf life.

This review attempts to summarize the recent progress in scientific research regarding the effect of agricultural practices, with special focus on Argentina's actions, on the improvement of nutritional value and quality characteristics of beef as a contribution to improve beef healthiness and global food security. The paper is organized in three sections that provide an outline of the lipids and proteins in beef and an overview of beef production systems in Argentina as a particular case for maximising its beneficial effects and minimising its negative impacts.

\section{Lipids}

2.1. Importance of Lipids in the Diet. In the last decades, there has been an increased interest in ways to manipulate the fatty acid composition of meat, since it is seen to be a major source of fat in the human diet. Human health recommendations include a fat intake of $15-30 \%$ of total energy intake [9]. Since the relative amounts of polyunsaturated fatty acids (PUFA) and saturated fatty acids (SFA) seem to play a key role in a healthy and balanced diet, a fatty acid intake up to $10 \%$ of saturated fatty acids (SFA) and a ratio of PUFA to SFA (P : S ratio) above 0.4 are recommended. Among PUFA, the ratio n-6:n-3 should be under 4 [10].

Since SFA, specially 12:0, 14:0, and 16:0, have been traditionally associated with increased level of cholesterol in blood stream and, consequently, with coronary heart disease (CHD) and cardiovascular disease (CVD), their deleterious metabolic effects are questioned at present. A recent metaanalysis of epidemiologic studies carried out by Siri-Tarino et al. [11] found no significant evidence for concluding that SFA are associated with increased risk of coronary heart disease or cardiovascular disease. Nevertheless, there is still an important emphasis in reducing SFA since the beneficial effects associated with the substitution of SFA with n-3 PUFA [12].

More recently, conjugated linoleic acid (CLA) and long chain PUFA (n-3) contents, eicosapentaenoic acid (EPA) and docosahexaenoic acid (DHA), have also become imperative due to their multiple healthy metabolic effects, like reduction of the risk of cardiovascular disease, proper brain and visual development in fetal life, and maintenance of neural and visual tissues throughout life [13-17]. Recent studies have stated a beneficial effect of the n-3 fatty acid $\alpha$-linolenic acid, ALA, at the low dose of $4.4 \mathrm{~g}$ per day, a perfectly achievable dose by means of regular consumption of ALA-rich sources [18].

Beef and other ruminant products constitute important dietary source of CLA, especially cis-9, trans-11 isomer, identified as an important health promoter factor including antitumoral and anticarcinogenic activities [19]. Biological effects have been widely studied also for the trans-10, cis12 isomer, identified as an important antiobesity factor [20]. Beef also contains trans-fatty acids (TFA), being vaccenic acid, trans-11 18:1, its most representative one. An intake of TFA lower than $1 \%$ of dietary energy has been recommended [21]. Nevertheless, in the last years, TFA became also very important since its potential protective properties against the development of coronary heart diseases [19]. Thus, at present, a great deal of effort is being done in differentiating natural from industrial TFA.

\subsection{Factors That Modify Beef Lipid Content and FA Profile.} Fat content and FA composition of beef may differ according to breed or genotype, the feeding background, and the muscle considered. Although beef usually has a P : S ratio around 0.1 , its ratio n-6:n-3 PUFA is particularly beneficial (around 2), especially from animals fed with grass containing high levels of PUFA n-3 [22]. Both, genetic and nutritional approaches have been widely studied in relation to FA profile of beef. In this regard, it is recognized that genetic factors provide smaller differences than nutritional ones [23]. Genetic factors reflect differences in gene expressions of enzymes involved in fatty acid synthesis. Thus, a particular relationship between fatness and FA profile has been stated [13]. As the content of SFA and MUFA increases with increasing fatness, the relative proportion of PUFA and the consequent P : S ratio decrease 
with it. Hence, lean meat with low fat content, less than $1 \%$, would contain a healthier $\mathrm{P}: \mathrm{S}$ ratio than high fat meat [24].

Regarding the effect of the diet, that is, the production system, it has been demonstrated that ruminants meat contains beneficial ratio of n-6:n-3 PUFA, that is, below 4, especially when they had consumed grass-based diets [22]. Beef from pasture-finished steers has greater levels of n-3 PUFA when compared to concentrate-finished steers $[25,26]$. Similar results were also found in pasture-finished bulls [27]. Moreover, fresh and conserved (silage and hay) grass presents different effects on the n-3 PUFA deposition into the muscle. Thus, higher levels of n-3 PUFA in the muscle of cattle fed fresh grass has been demonstrated than cattle fed hay [13]. An overall and compact view about the effect of different diets, from different production systems, is shown in Table 1. In this table, data regarding lipid content of $L D$ muscle and its FA composition is compiled as a general example of the major effects of animal feeding on beef quality.

It is important to remark that muscle lipids are distributed in different compartments or fractions. Thus, neutral fraction, usually characterized by high proportions of SFA and monounsaturated fatty acids (MUFA), is located along the muscle fibres, in the interfascicular area, and in cytosolic droplets into the muscle cells. This FA fraction is easily influenced by diet composition despite the saturation occurring at ruminal level. On the other hand, the polar fraction, composed by phospholipids and usually characterized by high proportion of PUFA, is located in the cell membranes. Due to the higher proportion of phospholipids, genetically lean breeds show higher levels of PUFA [34]. This FA fraction can be less influenced by diet and its content is independent of the total fat content [35]. Moreover, the fatty acid composition might also display a muscle effect, since muscle fiber type can affect fatty acid composition: red, oxidative, muscles have higher proportion of phospholipids and, therefore, contain higher levels of PUFA than white, glycolytic, muscles [22]. In this regard, Enser et al. [36] have reported a $\mathrm{P}: \mathrm{S}$ ratio in Gluteo biceps muscle, oxidative, red muscle, significantly higher than in the whiter Longissimus muscle in grass-fed steers.

2.3. Influence of FA Profile on Beef Quality Traits. Fatty acids are also involved in several physicochemical properties of meat, contributing not only to the nutritional attributes of beef but also to the physicochemical ones. Thus, different fatty acids (saturated or unsaturated) show different melting points, which in turn affects the firmness or softness of meat fat. On the other hand, the presence and degree of double bonds in the fatty acid structure affect the oxidation susceptibility, which in turn regulates the shelf life of meat [22].

Marbling fat, total fatty acid content in muscle, has been long recognized as a quality factor of meat. It has been also positively associated with juiciness and tenderness, although its contribution is indirect. It has been proposed that neutral lipids in fat cells could have a physical effect in separating muscle fiber bundles. It has been proposed that lipids could also retain water in the muscle structure leading to increased water holding capacity and associated juiciness [22].
TABLE 1: Lipid content and fatty acid composition reported of beef muscle from steers (British and crossbred) finished in different and contrasting production systems.

\begin{tabular}{|c|c|c|c|c|}
\hline & \multicolumn{3}{|c|}{ Production system } & \multirow{2}{*}{ Reference } \\
\hline & Pasture & Supplementation & Feedlot & \\
\hline \multirow{6}{*}{$\operatorname{IMF}(\%)$} & $2.86 \mathrm{~b}$ & $4.09 \mathrm{a}$ & $3.85 \mathrm{a}$ & {$[25]$} \\
\hline & 4.96 & & 4.52 & {$[28]$} \\
\hline & 2.83 & & & [29] \\
\hline & $0.98 \mathrm{~b}$ & & $1.30 \mathrm{a}$ & [30] \\
\hline & $2.80 \mathrm{~b}$ & & $4.40 \mathrm{a}$ & {$[31]$} \\
\hline & $2.12 \mathrm{~b}$ & & $3.61 \mathrm{a}$ & {$[32]$} \\
\hline \multirow{6}{*}{$\begin{array}{l}\text { SFA ( } \% \text { total } \\
\text { FA) }\end{array}$} & $38.40 \mathrm{a}$ & $37.85 \mathrm{a}$ & $35.33 \mathrm{~b}$ & {$[25]$} \\
\hline & 46.61 & & 45.80 & [28] \\
\hline & 43.1 & & & [29] \\
\hline & 38.76 & & 39.27 & {$[30]$} \\
\hline & $48.80 \mathrm{a}$ & & $45.10 \mathrm{~b}$ & {$[31]$} \\
\hline & $42.45 \mathrm{~b}$ & & $43.43 \mathrm{a}$ & {$[32]$} \\
\hline \multirow{6}{*}{$\begin{array}{l}\text { MUFA (\% } \\
\text { total FA) }\end{array}$} & $37.74 \mathrm{~b}$ & 40.89 a & $40.77 \mathrm{a}$ & [25] \\
\hline & 41.63 & & 37.35 & {$[28]$} \\
\hline & 30.2 & & & [29] \\
\hline & $24.69 \mathrm{~b}$ & & $34.99 \mathrm{a}$ & {$[30]$} \\
\hline & $42.50 \mathrm{~b}$ & & $46.20 \mathrm{a}$ & {$[31]$} \\
\hline & $43.87 \mathrm{~b}$ & & $47.89 \mathrm{a}$ & [32] \\
\hline \multirow{5}{*}{$\begin{array}{l}\text { PUFA (\% } \\
\text { total FA) }\end{array}$} & $7.95 \mathrm{a}, \mathrm{b}$ & $7.50 \mathrm{~b}$ & $9.31 \mathrm{a}$ & {$[25]$} \\
\hline & $5.58 \mathrm{~b}$ & & $10.12 \mathrm{a}$ & {$[28]$} \\
\hline & 8.73 & & & [29] \\
\hline & 28.99 a & & $19.06 \mathrm{~b}$ & {$[30]$} \\
\hline & $3.41 \mathrm{a}$ & & $2.77 \mathrm{~b}$ & {$[31]$} \\
\hline \multirow{3}{*}{ PUFA/SFA } & $0.21 \mathrm{~b}$ & $0.20 \mathrm{~b}$ & $0.27 \mathrm{a}$ & [25] \\
\hline & $0.12 \mathrm{~b}$ & & $0.23 \mathrm{a}$ & {$[28]$} \\
\hline & 0.20 & & & {$[29]$} \\
\hline \multirow{6}{*}{$n-6 / n-3$} & $1.72 \mathrm{c}$ & $3.77 \mathrm{~b}$ & $10.38 \mathrm{a}$ & {$[25]$} \\
\hline & $2.47 \mathrm{~b}$ & & $5.50 \mathrm{a}$ & {$[28]$} \\
\hline & 1.47 & & & [29] \\
\hline & $1.77 \mathrm{~b}$ & & $8.99 \mathrm{a}$ & {$[30]$} \\
\hline & $2.78 \mathrm{~b}$ & & $13.60 \mathrm{a}$ & {$[31]$} \\
\hline & $1.96 \mathrm{~b}$ & & $3.57 \mathrm{a}$ & [32] \\
\hline \multirow{2}{*}{$\begin{array}{l}\text { CLA (\% total } \\
\text { FA) }\end{array}$} & $0.72 \mathrm{a}$ & $0.58 \mathrm{~b}$ & $0.31 \mathrm{c}$ & {$[25]$} \\
\hline & 0.33 & & & [33] \\
\hline
\end{tabular}

IMF: intramuscular fat; SFA: saturated fatty acid; MUFA: monounsaturated fatty acid; PUFA: polyunsaturated fatty acid; CLA: conjugated linoleic acid. a, b, c mean values in row with different letters differ statistically $(P<0.05)$.

Flavour development during cooking also depends on the PUFA content of meat fat which leads the volatile compounds generation. Nevertheless, the desirable increase of PUFA in beef has the disadvantage of increasing the susceptibility to oxidation. In this regard, it has been stated that lipid oxidation is the major cause of colour, flavour, and nutritional value deterioration in meat [37]. Consequently, much effort has been made to protect these unsaturated structures by means of antioxidants elements like vitamin E [38-40]. 
Regarding this issue, it has been demonstrated that pasture production systems not only increase n-3 PUFA in beef but also increase vitamin E, $\alpha$-tocopherol, carotenoids, and flavonoids, extending its lipid stability and colour shelf life $[39,41]$. Grain production systems may improve the beef colour stability and shelf life by supplementing the animal diet with natural antioxidants, that is, $\alpha$-tocopherol [42].

Cooking procedures may affect the fat content and FA profile of both pasture- and feedlot-finished beef in a similar way [30]. Interesting data regarding the effect of cooking methods upon the nutritional quality of beef intramuscular fat has also been recently published. The effect of boiling, microwaving, and grilling on the composition and nutritional quality of beef intramuscular fat has been investigated. Results obtained demonstrated that the content of total lipids increased, by means of a concentration effect, with the cooking time and internal temperature reached [30]. The major changes in FA composition resulted in higher percentages of SFA and MUFA and lower levels of PUFA in cooked meat. CLA had revealed great stability to thermal processes [30].

\section{Proteins}

3.1. Importance of Proteins in the Diet. Meat muscle composition is approximately $19 \%$ proteins, being $11.5 \%$ structural proteins (myofibrillar), 5.5\% soluble sarcoplasmic proteins, and $2 \%$ connective tissue (collagen and elastin), and $2.5 \%$ fat, dispersed among protein fibers [43]. The protein content is modified in cooked meat due to water loss through the cooking process. These proteins become highly digestible (94\%) [44].

Paddon-Jones and Leidy [45] stated that red meat is a source of high quality protein and highly bioavailable iron to enhance vitality. Several authors have reported the ability of high quality proteins to promote weight loss, prevent weight gain and weight regain in adults [46-48], reduce fat mass [49], and protect against reductions in lean body mass [5053]. Losses in high quality protein, especially in older adults, cause sarcopenia (degenerative loss of skeletal muscle mass) and sarcopenic obesity by replacing lost skeletal muscle into fat $[45,54,55]$. Consequently, increasing consumption of high quality protein from middle age has been recommended in order to maintain the quality of life associated with adequate muscle mass. Protein content would maintain or increase fatfree mass by favouring a stimulatory effect on muscle protein anabolism in humans $[45,54-56]$.

Weight loss diets contain higher amounts of protein, which have been shown to be more effective compared to standard protein diets. Moreover, several authors showed a greater overall satisfaction in terms of food palatability, pleasure, and enjoyment in subjects consuming high protein diets as compared to lower protein diets [57-60].

3.2. Role of Aminoacids in Human Health. Aminoacids and bioactive compounds are very important molecules to prevent muscle-wasting diseases, that is, sarcopenia, to reduce calorie intake (metabolic syndrome prevention), to control blood pressure homeostasis, via ACE-inhibitory components from the connective tissue, and to maintain the functionality of intestinal environment, through nucleotides and nucleosides of meat [61].

Aminoacids like leucine, isoleucine, and valine are essential for protein synthesis. Leucine supplementation has been shown to increase muscle protein synthesis in older adults [62]. Furthermore, protein ingestion strongly increases muscle protein synthesis rates, effect mainly attributed to the stimulatory effect of essential aminoacids [63]. Beef also contains high amounts of glutamic acid/glutamine (16.5\%), arginine, alanine, and aspartic acid.

Phillips [64] reported that senescent muscle is less sensitive to the anabolic properties of aminoacids. Leucine has been reported to stimulate muscle protein synthesis in an insulin dependent and independent manner. Consequently, it has been suggested that increasing the leucine content of meals in the elderly could compensate the decreased muscle protein synthetic response to food intake.

Beef is also rich in branched-chain aminoacids, leading to further metabolic effects. Thus, comparing beef with soya, Phillips [64] has reported greater myofibrillar proteins synthesis, both at rest and after performance of resistance exercise, in those individuals submitted to beef feeding. Moreover, Bhutta [65] stated that meat proteins provide all essential aminoacids (lysine, threonine, methionine, phenylalanine, tryptophan, leucine, isoleucine, and valine) with no limiting aminoacid.

3.3. Biopeptides. Bioactive peptides are sequences of 230 aminoacids that impart a positive health effect to the consumer when ingested, playing an important role in the prevention of diseases associated with the development of metabolic syndrome and mental health diseases [66].

Meat contains several proteins and peptides with important physiological activities. It has been demonstrated that collagen has a positive influence on the delivery and bioactivity of bone morphogenic protein-2 and ectopic bone formation, enhancing bone healing [67]. Other varieties of beneficial effects on health by meat peptides include antihypertensive, antioxidant, antithrombotic, anticancer, immune modulatory, and antimicrobial activities. In the last years, the possibility of obtaining bioactive peptides from meat proteins by means of different procedures like hydrolysis, cooking, and fermentation has been explored [68].

Some peptides are inactive in the sequence of the parent protein but may have a positive effect once released. A variety of bioactive peptides are naturally occurring in animals or are generated post mortem by endogenous enzymes in meat and [69].

At present, there is insufficient information about the physiological functions of beef peptides in both animal and human models. Thus, the study of the beef proteins as precursors of functional biopeptides, in order to develop functional foods and nutraceuticals, remains a great issue to be explored [70].

Although several bioactive compounds in meat, carnosine, anserine, and L-carnitine, have been recently studied, 
the effect of beef production systems on these bioactive compounds remains almost unexplored. Recent studies [71] demonstrated that preslaughter management can affect the beef content of anserine and carnosine, both in extensive (pasture-based) and in intensive (grain-based) systems. Carnosine beef content also displayed a production systemassociated behaviour, with higher levels in pastured-based beef when compared to intensive-based beef [71]. However, Arihara [72] reported that there are still some obstacles in the development and marketing of new functional meat products as these products are unconventional.

\section{The Argentinean Perspective of Beef Production Systems and Implications on Meat Quality}

4.1. Argentinean Livestock Production Systems. Argentina is a well-known producer of pasture-fed beef. Traditionally, beef production was based on low-input systems, which combined grazing complemented with grain as energy supplements to provide pasture-finished beef. However, during the last two decades, Argentinean beef production has evolved into a diversification and intensification process of grazing systems as a result of cash crop expansion caused by the increase in grains prices.

In Argentina, the process of producing beef can be explained as divided into two main activities: (a) cow-calf on marginal lands and (b) steers growing and fattening on better soils [73]. At present, one-third of the cow-calf farmers retain calves and rear them on the same farm on grain supplemented pastures or in confinement until slaughter. The remaining two-thirds still produce calves on extensive cow-calf systems [74].

In the last years, less than $2 \%$ of rearing and fattening cattle farms of tempered regions practice pure grazing systems. Most farmers combine grain cropping with livestock in mixed systems. A field is normally kept with a legume-based perennial pasture for a 4-6-year period, followed by a period of annual forages and grain cropping. Rotation schemes depend on several factors, like soil quality, technology availability, and economics competence.

More than $70 \%$ of beef produced in Argentina is still produced in pasture-based systems, most widely spread in the temperate areas [74]. Those systems are the least energy intensive and rely on adjusted forage chains depending on rainfall, temperature, and soils quality. In rotation with grain cropping, forage chains include legume-based pastures (primarily alfalfa) and small-grain winter annuals crops (rye, oats, ryegrass, and triticale). Most cattle fattening farmers make a strategic use of energy supplement when necessary, being cereals grain (corn and sorghum) the most common supplement. More recently, confinement feeding at final stage of fattening has been introduced by some farmers.

Overall average daily gains of pasture-finished steers are in the 600 to $700 \mathrm{~g} /$ day range on $100 \%$ grazing systems. Slower cycles on pure grazing systems have lower average body weight daily gain and include feeding restriction in winter followed by compensatory growth of cattle in spring and summer. Growth continues at moderate rates during a second winter period, targeting full finishing the following spring or summer.

Confinement feeding was lately introduced as strategy to remove animals from grain cropping lands. Confinement feeding takes place at the end of grazing periods (finishing lots) or previous to the initiation of pasture programs, stocker phase, also called "beginning lots." Feedlots are more efficient in terms of land occupation but much less in terms of environmental impact, competition with human diet, and meat safety.

A brief scheme of the Argentinean beef production platform mentioned above is presented in Figure 1 (adapted from [75]).

4.2. Argentinean Market of Beef. In Argentina, market preferences for freshness and tenderness led the adjustments for beef quality. Argentinean consumers have a preference for fresh and lean beef. Additionally, the market does not have a taste for aged beef and most packing plants geared to the domestic market are not prepared for stocking beef beyond week. Therefore, beef tenderness has been accomplished by processing young and light, early maturing, easy fattening animals with body condition scores of 3-5.

The increasing world interest in tenderness, flavour, and lipid profiles has pushed research nationwide. Research has largely focused on attributes of beef generated on different feeding and grazing strategies. Previous studies [76-78] had reported that pasture-finished beef is less tender than concentrate-finished. Nevertheless, Argentinean studies [28, 79] have not detected such differences, by means of WB shear force, between grain and grass-fed beef finished to a similar fatness endpoint. Similarly, Realini et al. [80] found no differences between steaks from concentrate- and pasturefinished beef in Uruguay, despite differences found in carcass weight, fatness, and temperature during chilling. Likewise, Duckett et al. [81], French et al. [82], and Mandell et al. [83] found no differences in WB shear force ratings between feedlot-fed and pasture-fed beef in the US, when animals were finished to similar age or fatness.

Bearing in mind that the type of forage could affect beef characteristics, research on pasture finishing on different forages has been carried out. Pordomingo et al. [29, 84] finished steers on winter annuals (triticale, cereal rye, and wheat) or alfalfa to assess beef characteristics. The authors reported no effects of forage source on WB shear force, back-fat thickness, or hot carcass yield. Alfalfa-finished animals had in average more IMF than the grass-finished ones. Wheatfinished animals had a similar content to alfalfa-finished ones. Cereal rye yielded the animals with less desirable profiles compared with the other treatments. The meat quality parameters of shear force, panel tenderness scores, and colour were similar to those reported for feedlot-finished animals in other studies, in both Argentina [28, 85] and Uruguay [80].

Argentinean research suggests that pasture-finished beef is likely to be leaner and lower in cholesterol concentrations than feedlot beef [85-90]. Conversely, Rosso et al. [86] had reported the opposite for IMF content, considering animals 


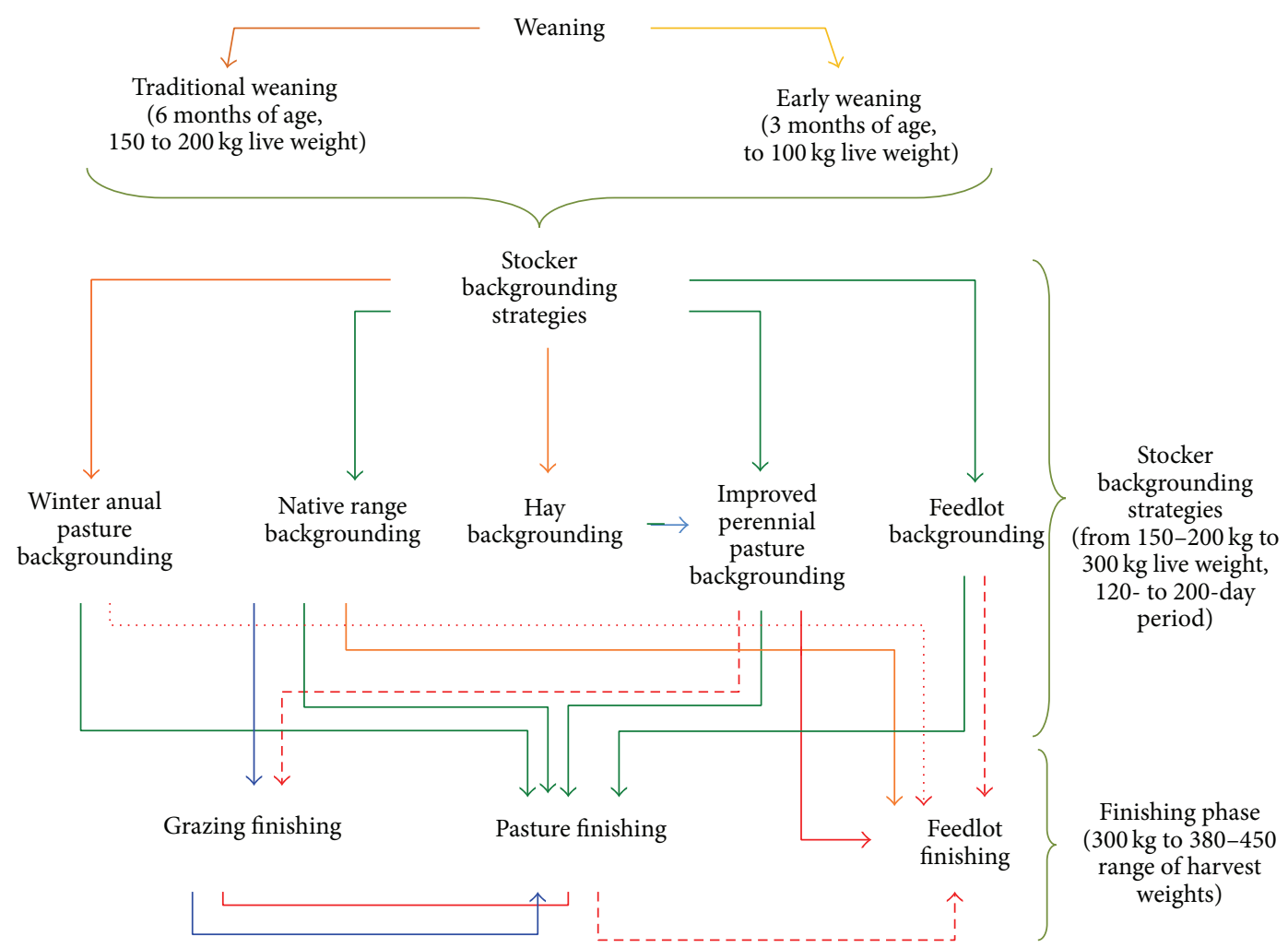

FIGURE 1: Illustrative platform of main beef production systems in Argentina.

of different age in their study. In turn, Volpi Lagreca et al. [28] reported no differences in IMF and back-fat content in feedlot- versus pasture-finished animals when fattened to a similar back-fat thickness and live weight endpoint.

Martínez Ferrer et al. [91] reported a trend $(P=0.11)$ towards a higher proportion of SFA in pasture-based beef, due to an increase in C18:0 $(P=0.047), \mathrm{C} 14: 0(P=$ 0.12), and C16:0 ( $P=0.37)$, from steers finished at $10 \mathrm{~mm}$ of subcutaneous fat depth. Most studies point out that the proportion of SFA would not be altered by feedlot fattening. Consistently, the highest PUFA concentrations were observed in pasture-based beef [29, 79, 85]. Volpi Lagreca et al. [28] detected greater PUFA n-6 concentrations in feedlot compared with pasture finishing (Table 1).

Most Argentinean studies which have finished steers on a starch-based diet $[28,79,85,90-93]$ reported greater n6/n-3 ratios compared with pasture diet (Table 1 ). It has been also demonstrated that the addition of supplemental grain on pasture systems would increase this ratio. On the other hand, studies of Martínez Ferrer et al. [90, 94] and Depetris et al. [95] pointed out that pasture grazing strongly ameliorates the effects of starch feeding on lipids profiles.

Carryover effects of supplementation [96] or feedlot backgrounding [29] on lipids profiles of pasture-finished cattle could be expected. The last authors compared feedlot backgrounding on diets with increasing content of hay with pasture backgrounding on pasture-finished heifers. Results demonstrated that grazing during 132 days after feedlot backgrounding removed only partially the effect of the starch-rich feedlot diets on the fatty acid profile of Longissimus dorsi of heifers. Omega 3 fatty acid concentrations remained higher for animals backgrounded on pasture or a $100 \%$ hay diet, compared to 40 and $70 \%$ hay diets.

Regarding CLA levels, Latimori et al. [79, 85] and Martínez Ferrer et al. $[90,94]$ have reported increased levels (3-fold) of CLA in pasture-finished beef, when compared to feedlot-finished beef of steers. Thus, while CLA concentration in IMF from animals grown and finished on alfalfa pastures is likely to be in the range of $0.7-0.8 \%$, grain supplementation on pasture would tend to reduce CLA content. Nevertheless, this CLA content of beef would double the level when compared to beef from grain or corn silage-based feedlot diets. Based on this evidence, it could be suggested that CLA content of beef would not be greatly affected by limited energy supplementation of grazing cattle on leguminous pastures.

Regarding the effect of feedlot feeding during a stocker program, Pordomingo et al. [29] noted that pasture-finished heifers, backgrounded in feedlot during 104 days, resulted in CLA beef contents below $0.5 \%$. No differential effects given to energy content of the feedlot-fed diet were detected. Results from this study suggest that systems that pursue CLA enriched beef would need to consider the nature of the diet from the early stages of the growing-finishing program.

\section{Conclusions}

Adequate management of beef production systems would constitute one of the major tools to improve beef quality 
in a sustainable way. Argentinean production systems may promote food security by means of animal feeding mainly based on feeds not used in human nutrition. They have demonstrated an improvement of beef healthiness, minimizing several negative effects associated with beef consumption, while containing the environmental impact.

Our thought is that research efforts must be stressed to deepen the current knowledge regarding the contribution of animal production systems to maintain beef safety and its biological composition during longer periods of time.

\section{Conflict of Interests}

The authors declare that there is no conflict of interests regarding the publication of this paper.

\section{Acknowledgments}

This review paper is a product of an ongoing discussion between the authors based on their research experience and knowledge published in recent literature, under an interdisciplinary sight given by their expertise. Financial and material support for the writing of this paper has been provided by National Institute of Agricultural Technology, INTA, and Morón University (UM) from Argentina.

\section{References}

[1] G. Paredi, M.-A. Sentandreu, A. Mozzarelli, S. Fadda, K. Hollung, and A. M. de Almeida, "Muscle and meat: new horizons and applications for proteomics on a farm to fork perspective," Journal of Proteomics, vol. 88, pp. 58-82, 2013.

[2] L. Wyness, "Nutritional aspects of red meat in the diet," in Nutritional and Climate Change: Major Issues Confronting the Meat Industry, J. D. Wood and C. Rowlings, Eds., pp. 1-22, Nottingham University Press, 2013.

[3] W. Zhang, S. Xiao, H. Samaraweera, E. J. Lee, and D. U. Ahn, "Improving functional value of meat products," Meat Science, vol. 86, no. 1, pp. 15-31, 2010.

[4] J.-F. Hocquette, R. Botreau, B. Picard, A. Jacquet, D. W. Pethick, and N. D. Scollan, "Review: opportunities for predicting and manipulating beef quality," Meat Science, vol. 92, no. 3, pp. 197209, 2012.

[5] C. Thomas, N. Scollan, and D. Moran, "A road map for the beef industry to meet the challenge of climate change-a discussion document," Animal Frontiers, vol. 1, no. 2, pp. 6-9, 2014.

[6] K. Tontisirin, G. Nantel, and L. Bhattacharjee, "Food-based strategies to meet the challenges of micronutrient malnutrition in the developing world," Proceedings of the Nutrition Society, vol. 61, no. 2, pp. 243-250, 2002.

[7] G. H. Zhou, X. L. Xu, and Y. Liu, "Preservation technologies for fresh meat-a review," Meat Science, vol. 86, no. 1, pp. 119-128, 2010.

[8] T. Aymerich, P. A. Picouet, and J. M. Monfort, "Decontamination technologies for meat products," Meat Science, vol. 78, no. 1-2, pp. 114-129, 2008.

[9] World Health Organization, Diet, Nutrition and Prevention of Chronic Diseases, vol. 916 of Report of the Joint WHO/FAO Expert Consultation, World Health Organization, Geneva, Switzerland, 2003.
[10] N. D. Scollan, D. Dannenberger, K. Nuernberg et al., "Enhancing the nutritional and health value of beef lipids and their relationship with meat quality," Meat Science, vol. 97, no. 3, pp. 384-394, 2014.

[11] P. W. Siri-Tarino, Q. Sun, F. B. Hu, and R. M. Krauss, "Metaanalysis of prospective cohort studies evaluating the association of saturated fat with cardiovascular disease," The American Journal of Clinical Nutrition, vol. 91, no. 3, pp. 535-546, 2010.

[12] P. W. Siri-Tarino, Q. Sun, F. B. Hu, and R. M. Krauss, "Saturated fat, carbohydrate, and cardiovascular disease," The American Journal of Clinical Nutrition, vol. 91, no. 3, pp. 502-509, 2010.

[13] N. D. Scollan, P. Costa, K. G. Hallett, G. R. Nute, J. D. Wood, and R. I. Richardson, "The fatty acid composition of muscle fat and relationships to meat quality in Charolais steers: influence of level of red clover in the diet," in Proceedings of the British Society of Animal Science, Winter, p. 23, BSAS, 2006.

[14] G. Barceló-Coblijn and E. J. Murphy, "Alpha-linolenic acid and its conversion to longer chain n-3 fatty acids: benefits for human health and a role in maintaining tissue $n-3$ fatty acid levels," Progress in Lipid Research, vol. 48, no. 6, pp. 355-374, 2009.

[15] P. T. Garcia and J. J. Casal, "Effect of dietary plant lipids on conjugated linoleic acid (CLA) concentrations in beef and lamb meats," in Soybean-Bio-Active Compounds, H. A. El-Shemy, Ed., pp. 135-159, InTech, Vienna, Austria, 2013.

[16] P. T. Garcia, "Metabolism of $\alpha$ - linolenic acid (ALA) in meat animals," in Soybean and Nutrition, H. El-Shemy, Ed., pp. 349368, InTech, 2011.

[17] E. Lopez-Huertas, "Health effects of oleic acid and long chain omega-3 fatty acids (EPA and DHA) enriched milks. A review of intervention studies," Pharmacological Research, vol. 61, no. 3, pp. 200-207, 2010.

[18] S. Egert, F. Kannenberg, V. Somoza, H. F. Erbersdobler, and U. Wahrburg, "Dietary \&-linolenic acid, EPA, and DHA have differential effects on LDL fatty acid composition but similar effects on serum lipid profiles in normolipidemic humans," Journal of Nutrition, vol. 139, no. 5, pp. 861-868, 2009.

[19] A. M. Salter, "Dietary fatty acids and cardiovascular disease," Animal, vol. 7, no. 1, pp. 163-171, 2013.

[20] M. A. Belury, "Conjugated linoleic acids in type 2 diabetes mellitus: implications and potential mechanisms," in Advances in Conjugated Linoleic Acid Research, J. L. Sebedio, W. W. Christie, and R. O. Adlof, Eds., vol. 2, pp. 267-281, AOCA Press, Champaign, Ill, USA, 2003.

[21] W. C. Willet, "The scientific basis for TFA regulation-is it sufficient?" in Proceedings of the 1st International Symposisium on Trans Fatty Acids and Health, p. 24, Rungstedgaard, Denmark, September 2005.

[22] J. D. Wood, R. I. Richardson, G. R. Nute et al., "Effects of fatty acids on meat quality: a review," Meat Science, vol. 66, no. 1, pp. 21-32, 2004.

[23] S. De Smet, K. Raes, and D. Demeyer, "Meat fatty acid composition as affected by fatness and genetic factors: a review," Animal Research, vol. 53, no. 2, pp. 81-98, 2004.

[24] K. Raes, S. De Smet, and D. Demeyer, "Effect of doublémuscling in Belgium Blue Young bulls on the intramuscular fatty acid composition with emphasis on conjugated linoleic acid and polyunsaturated fatty acids," Animal Science, vol. 73, pp. 253-260, 2001.

[25] P. T. Garcia, N. A. Pensel, A. M. Sancho et al., "Beef lipids in relation to animal breed and nutrition in Argentina," Meat Science, vol. 79, no. 3, pp. 500-508, 2008. 
[26] P. French, E. G. O’Riordan, F. J. Monahan, P. J. Caffrey, and A. P. Moloney, "Fatty acid composition of intramuscular triacylglycerols of fed autumn grass and concentrates," Livestock Production Science, vol. 81, pp. 307-317, 2003.

[27] S. Lorenz, A. Buttner, K. Ender et al., "Influence of keeping system on fatty acid composition in the longissimus muscle of bulls and odorants formed after pressure-cooking," European Food Research Technology, vol. 214, no. 2, pp. 112-118, 2002.

[28] G. Volpi Lagreca, A. J. Pordomingo, M. Alende, and P. T. García, Grasa Intramuscular y Perfíl de Ácidos Grasos de la Carne de Novillos con Diferentes Estrategias de Recría o Terminación. Avances en Calidad de Carne Bovina. Implicancias de la Alimentación, la Genética y el Manejo, vol. 92, Publicación Técnica INTA EEA Anguil, La Pampa, Argentine, 2013.

[29] A. J. Pordomingo, T. P. García, and G. V. Lagreca, "Effect of feeding treatment during the backgrounding phase of beef production from pasture on: II. Longissimus muscle proximate composition, cholesterol and fatty acids," Meat Science, vol. 90, no. 4, pp. 947-955, 2012.

[30] C. M. M. Alfaia, S. P. Alves, A. F. Lopes et al., "Effect of cooking methods on fatty acids, conjugated isomers of linoleic acid and nutritional quality of beef intramuscular fat," Meat Science, vol. 84, no. 4, pp. 769-777, 2010.

[31] J. M. Leheska, L. D. Thompson, J. C. Howe et al., "Effects of conventional and grass-feeding systems on the nutrient composition of beef," Journal of Animal Science, vol. 86, no. 12, pp. 3575-3585, 2008.

[32] E. N. Ponnampalam, N. J. Mann, and A. J. Sinclair, "Effect of feeding systems on omega-3 fatty acids, conjugated linoleic acid and trans fatty acids in Australian beef cuts: potential impact on human health," Asia Pacific Journal of Clinical Nutrition, vol. 15, no. 1, pp. 21-29, 2006.

[33] V. Muchenje, A. Hugo, K. Dzama, M. Chimonyo, P. E. Strydom, and J. G. Raats, "Cholesterol levels and fatty acid profiles of beef from three cattle breeds raised on natural pasture," Journal of Food Composition and Analysis, vol. 22, no. 4, pp. 354-358, 2009.

[34] A. Braghieri, G. F. Cifuni, A. Girolami, A. M. Riviezzi, I. Marsico, and F. Napolitano, "Chemical, physical and sensory properties of meat from pure and crossbred Podolian bulls at different ageing times," Meat Science, vol. 69, no. 4, pp. 681-689, 2005.

[35] K. Raes, S. De Smet, and D. Demeyer, "Effect of dietary fatty acids on incorporation of long chain polyunsaturated fatty acids and conjugated linoleic acid in lamb, beef and pork meat: a review," Animal Feed Science and Technology, vol. 113, no. 1-4, pp. 199-221, 2004.

[36] M. Enser, K. G. Hallett, B. Hewett, G. A. J. Fursey, J. D. Wood, and G. Harrington, "Fatty acid content and composition of UK beef and lamb muscle in relation to production system and implications for human nutrition," Meat Science, vol. 49, no. 3 , pp. 329-341, 1998.

[37] Y. F. Li and S. M. Liu, "Reducing lipid peroxidation for improving colour stability of beef and lamb: on-farm considerations," Journal of the Science of Food and Agriculture, vol. 92, no. 4, pp. 719-729, 2012.

[38] A. Yang, M. C. Lanari, M. Brewster, and R. K. Tume, "Lipid stability and meat colour of beef from pasture- and grain-fed cattle with or without vitamin E supplement," Meat Science, vol. 60, no. 1, pp. 41-50, 2002.

[39] A. M. Descalzo and A. M. Sancho, "A review of natural antioxidants and their effects on oxidative status, odor and quality of fresh beef produced in Argentina," Meat Science, vol. 79, no. 3, pp. 423-436, 2008.

[40] C. A. Daley, A. Abbott, P. S. Doyle, G. A. Nader, and S. Larson, "A review of fatty acid profiles and antioxidant content in grassfed and grain-fed beef," Nutrition Journal, vol. 9, article 10, 2010.

[41] H. E. Warren, N. D. Scollan, G. R. Nute, S. I. Hughes, J. D. Wood, and R. I. Richardson, "Effects of breed and a concentrate or grass silage diet on beef quality in cattle of 3 ages. II: meat stability and flavour," Meat Science, vol. 78, no. 3, pp. 270-278, 2008.

[42] R. T. Nassu, M. E. R. Dugan, M. Juárez, J. A. Basarab, V. S. Baron, and J. L. Aalhus, "Effect of $\alpha$-tocopherol tissue levels on beef quality, Animal, vol. 5, no. 12, pp. 2010-2018, 2011.

[43] A. Bender, Meat and Meat Products in Human Nutrition in Developing Countries, Food and Nutrition Paper 53, Animal Production and Health Division, Food and Agriculture Organization of The United Nations, Rome, Italy, 1992, http://www.fao .org/docrep/t0562e/T0562E00.HTM.

[44] P. Williams, "Nutritional composition of red meat," Nutrition \& Dietetics, vol. 64, supplement 4, pp. S113-S119, 2007.

[45] D. Paddon-Jones and H. Leidy, "Dietary protein and muscle in older persons," Current Opinion in Clinical Nutrition and Metabolic Care, vol. 17, no. 1, pp. 5-11, 2014.

[46] B. J. Brehm and D. A. D’Alessio, "Benefits of high-protein weight loss diets: enough evidence for practice?" Current Opinion in Endocrinology, Diabetes \& Obesity, vol. 15, no. 5, pp. 416-421, 2008.

[47] T. L. Halton and F. B. Hu, "The effects of high protein diets on thermogenesis, satiety and weight loss: a critical review," Journal of the American College of Nutrition, vol. 23, no. 5, pp. 373-385, 2004.

[48] M. S. Westerterp-Plantenga, A. Nieuwenhuizen, D. Tomé, S. Soenen, and K. R. Westerterp, "Dietary protein, weight loss, and weight maintenance," Annual Review of Nutrition, vol. 29, pp. 21-41, 2009.

[49] U. Keller, "Dietary proteins in obesity and in diabetes," International Journal for Vitamin and Nutrition Research, vol. 81, no. 2-3, pp. 125-133, 2011.

[50] M. J. Bopp, D. K. Houston, L. Lenchik, L. Easter, S. B. Kritchevsky, and B. J. Nicklas, "Lean mass loss is associated with low protein intake during dietary-induced weight loss in postmenopausal women," Journal of the American Dietetic Association, vol. 108, no. 7, pp. 1216-1220, 2008.

[51] R. F. Kushner and B. Doerfler, "Low-carbohydrate, high-protein diets revisited," Current Opinion in Gastroenterology, vol. 24, no. 2, pp. 198-203, 2008.

[52] D. S. Weigle, P. A. Breen, C. C. Matthys et al., "A high-protein diet induces sustained reductions in appetite, ad libitum caloric intake, and body weight despite compensatory changes in diurnal plasma leptin and ghrelin concentrations," The American Journal of Clinical Nutrition, vol. 82, no. 1, pp. 41-48, 2005.

[53] T. P. Wycherley, L. J. Moran, P. M. Clifton, M. Noakes, and G. D. Brinkworth, "Effects of energy-restricted high-protein, low-fat compared with standard-protein, low-fat diets: a metaanalysis of randomized controlled trials," The American Journal of Clinical Nutrition, vol. 96, no. 6, pp. 1281-1298, 2012.

[54] D. Paddon-Jones and B. B. Rasmussen, "Dietary protein recommendations and theprevention of sarcopenia," Current Opinion in Clinical Nutrition and Metabolic Care, vol. 12, no. 1, pp. 86-90, 2009.

[55] D. Paddon-Jones, K. R. Short, W. W. Campbell, E. Volpi, and R. R. Wolfe, "Role of dietary protein in the sarcopenia of aging," 
American Journal of Clinical Nutrition, vol. 87, no. 5, pp. 1562S1566S, 2008.

[56] T. A. Churchward-Venne, C. H. Murphy, T. M. Longland, and S. M. Phillips, "Role of protein and amino acids in promoting lean mass accretion with resistance exercise and attenuating lean mass loss during energy deficit in humans," Amino Acids, vol. 45, no. 2, pp. 231-240, 2013.

[57] D. K. Layman, E. Evans, J. I. Baum, J. Seyler, D. J. Erickson, and R. A. Boileau, "Dietary protein and exercise have additive effects on body composition during weight loss in adult women," Journal of Nutrition, vol. 135, no. 8, pp. 1903-1910, 2005.

[58] D. K. Layman, E. M. Evans, D. Erickson et al., "A moderateprotein diet produces sustained weight loss and long-term changes in body composition and blood lipids in obese adults," Journal of Nutrition, vol. 139, no. 3, pp. 514-521, 2009.

[59] H. J. Leidy, N. S. Carnell, R. D. Mattes, and W. W. Campbell, "Higher protein intake preserves lean mass and satiety with weight loss in pre-obese and obese women," Obesity, vol. 15, no. 2, pp. 421-429, 2007.

[60] A. McConnon, G. W. Horgan, C. Lawton et al., "Experience and acceptability of diets of varying protein content and glycemic index in an obese cohort: results from the Diogenes trial," European Journal of Clinical Nutrition, vol. 67, no. 9, pp. 990995, 2013.

[61] J. F. Young, M. Therkildsen, B. Ekstrand et al., "Novel aspects of health promoting compounds in meat," Meat Science, vol. 95, no. 4, pp. 904-911, 2013.

[62] S. H. McNeill, "Inclusion of red meat in healthful dietary patterns," Meat Science, vol. 98, no. 3, pp. 452-460, 2014.

[63] B. T. Wall, H. M. Hamer, A. de Lange et al., "Leucine coingestion improves post-prandial muscle protein accretion in elderly men," Clinical Nutrition, vol. 32, no. 3, pp. 412-419, 2013.

[64] S. M. Phillips, "Nutrient-rich meat proteins in offsetting agerelated muscle loss," Meat Science, vol. 92, no. 3, pp. 174-178, 2012.

[65] Z. Bhutta, "Protein: digestibility and availability," in Encyclopedia of Human Nutrition, M. Sadler, J. Strain, and B. Caballero, Eds., pp. 1646-1656, Academic Press, San Diego, Calif, USA, 1999.

[66] T. Lafarga and M. Hayes, "Bioactive peptides from meat muscle and by-products: generation, functionality and application as functional ingredients," Meat Science, vol. 98, no. 2, pp. 227-239, 2014.

[67] G. Bhakta, Z. X. H. Lim, B. Rai et al., “The influence of collagen and hyaluronan matrices on the delivery and bioactivity of bone morphogenetic protein-2 and ectopic bone formation," Acta Biomaterialia, vol. 9, no. 11, pp. 9098-9106, 2013.

[68] R. Di Bernardini, P. Harnedy, D. Bolton et al., "Antioxidant and antimicrobial peptidic hydrolysates from muscle protein sources and by-products," Food Chemistry, vol. 124, no. 4, pp. 1296-1307, 2011.

[69] M. A. Sentandreu, G. Coulis, and A. Ouali, "Role of muscle endopeptidases and their inhibitors in meat tenderness," Trends in Food Science \& Technology, vol. 13, no. 12, pp. 400-421, 2002.

[70] C. Chibuike and A. H. Udenigwe, "Meat proteome as source of functional biopeptides," Food Research International, vol. 54, no. 1, pp. 1021-1032, 2013.

[71] V. Chamorro, A. A. Pazos, M. F. Godoy et al., "Histidine dipeptides and free amino acids of beef cattle raised under contrasting feeding systems and pre-slaughter management," in Proceedings of the 60th International Congress of Meat Science and Technology, Maldonado, Uruguay, August 2014.
[72] K. Arihara, "Strategies for designing novel functional meat products," Meat Science, vol. 74, no. 1, pp. 219-229, 2006.

[73] D. H. Rearte, "Beef cattle production and meat quality on grazing system in temperate region," in Proceeding of the 8th World Conference on Animal Production, vol. 2 of Symposium Series, pp. 80-91, Seoul, South Korea, July 1998.

[74] A. J. Pordomingo, "Argentinean beef systems," Stockman Grassfarmer Magazine, vol. 3, pp. 1-8, 2009.

[75] D. H. Rearte and A. J. Pordomingo, "The relevance of methane emissions from beef production and the challenges of the Argentinean beef production platform," Meat Science, vol. 98, no. 3, pp. 355-360, 2014.

[76] G. E. Mitchell, A. W. Reed, and S. E. Rogers, "Influence of feeding regimen on the sensory qualities and fatty acid contents of beef steaks," Journal of Food Science, vol. 56, pp. 1102-1103, 1991.

[77] L. L. Bennett, A. C. Hammond, M. J. Williams et al., "Performance, carcass yield, and carcass quality characteristics of steers finished on rhizome peanut (Arachis glabrata)-tropical grass pasture or concentrate," Journal of Animal Science, vol. 73, pp. 1881-1887, 1995.

[78] H. B. Hedrick, J. A. Paterson, A. G. Matches et al., "Carcass and palatability characteristics of beef produced on pasture, cornsilage and corn grain," Journal of Animal Science, vol. 57, no. 4, pp. 791-801, 1983.

[79] N. J. Latimori, A. M. Kloster, M. A. Amigone, P. T. García, F. J. Carduza, and N. A. Pensel, "Calidad de la carne bovina según genotipo y sistema de alimentación," Revista Argentina de Producción Animal, vol. 25, supplement 1, pp. 365-367, 2005.

[80] C. E. Realini, S. K. Duckett, G. W. Brito, M. D. Rizza, and D. de Mattos, "Effect of pasture vs. concentrate feeding with or without antioxidants on carcass characteristics, fatty acid composition, and quality of Uruguayan beef," Meat Science, vol. 66, no. 3, pp. 567-577, 2004.

[81] S. K. Duckett, J. P. S. Neel, R. N. Sonon Jr., J. P. Fontenot, W. M. Clapham, and G. Scaglia, "Effects of winter stocker growth rate and finishing system on: II. Ninth-tenth-eleventh-rib composition, muscle color, and palatability," Journal of Animal Science, vol. 85, no. 10, pp. 2691-2698, 2007.

[82] P. French, C. Stanton, F. Lawless et al., "Fatty acid composition, including conjugated linoleic acid, of intramuscular fat from steers offered grazed grass, grass silage, or concentrate based diets," Journal of Animal Science, vol. 78, no. 11, pp. 2849-2855, 2000.

[83] I. B. Mandell, J. G. Buchanan-Smith, and C. P. Campbell, "Effects of forage vs grain feeding on carcass characteristics, fatty acid composition, and beef quality in Limousin-cross steers when time on feed is controlled," Journal of Animal Science, vol. 76, no. 10, pp. 2619-2630, 1998.

[84] A. J. Pordomingo, G. Grigioni, F. Carduza, and G. Volpi Lagreca, "Effect of feeding treatment during the backgrounding phase of beef production from pasture on: I. Animal performance, carcass and meat quality," Meat Science, vol. 90, no. 4, pp. 939946, 2012.

[85] N. J. Latimori, A. M. Kloster, P. T. García, F. J. Carduza, G. Grigioni, and N. A. Pensel, "Diet and genotype effects on the quality index of beef produced in the Argentine Pampeana region," Meat Science, vol. 79, no. 3, pp. 463-469, 2008.

[86] O. Rosso, P. T. García, and C. Machado, Modelos experimentales de engorde de novillos y su efecto sobre la ganancia de peso, parámetros sanguíneos, calidad de la res y niveles de grasa 
intramuscular y colesterol en carne. Informe técnico carta acuerdo INTAA-ACREA-Facultad de Ciencias Veterinarias UNNE, 1998.

[87] V. Schindler, M. E. Cossu, G. Trinchero, J. J. Grigera Naón, F. Canosa, and L. Santa Coloma, "Effect of feeding system on daily gain of steers, fat and cholesterol content of beef," in Proceedings of the 46th International Congress of Meat Science and Technology, pp. 171-172, 2000.

[88] V. Schindler de Avila, L. Pruzzo, D. Arieu, and L. F. de Santa Coloma, "Evaluación de terneza de reses de novillos Hereford bajo distintos modelos de invernada," Revista Argentina de Producción Animal, vol. 23, no. 1, pp. 351-352, 2003.

[89] J. Martínez Ferrer, E. Ustarroz, G. Teira, F. Perlo, P. Bonato, and O. Tisocco, "Efecto del sistema de alimentación sobre lacalidad de carne bovina. 1. Características sensoriales," Revista Argentina de Producción Animal, vol. 26, supplement 1, pp. 387388, 2006.

[90] J. Martínez Ferrer, E. Ustarroz, G. Teira, F. Perlo, P. Bonato, and O. Tisocco, "Efecto del sistema de alimentación sobre lacalidad de carne bovina. 2. Características físicoquímicas," Revista Argentina de Producción Animal, vol. 26, no. S1, pp. 388$389,2006$.

[91] J. Martínez Ferrer, E. Ustarroz, C. G. Ferrayoli, and D. Alomar, "The effects of grazing intensification, silage or grain based diets for beef production in sub-humid Argentina on steer performance and meat fatty acid composition," in Utilisation of Grazed Grass in Temperate Animal Systems. Proceedings of a Satellite Workshop of the 20th International Grassland Congress, July 2005, Cork, Ireland, J. J. Murphy, Ed., p. 253, 2005.

[92] M. E. Cossu, L. Pruzzo, G. Trinchero, F. Canosa, J. J. Grigera Na, and L. Santa Coloma, "Fatty acid composition on longissimus muscle of steers fattened under different feeding regimes," in Proceedingsof the 46th International Congress of Meat Science and Technology, pp. 178-179, 2000.

[93] P. T. García, N. A. Pensel, N. J. Latimori, A. M. Kloster, M. A. Amigone, and J. J. Casal, "Intramuscular lipids in steers under different grass and grain regimen," Fleischwirtschaft International, vol. 1, pp. 27-31, 2005.

[94] J. Martínez Ferrer, E. Ustarroz, C. G. Ferrayoli, M. A. Brunetti, J. Simondi, and M. de León, "Concentración de ácidolinoleico conjugado (c9,t11CLA) y perfil de ácidos grasos en la carne denovillos sometidos a diferentes regímenes de alimentación," Revista Argentina de Producción Animal, vol. 24, supplement 1, pp. 13-15, 2004.

[95] G. Depetris, F. Santini, E. Pavan, E. Villarreal, and P. T. García, "Perfil de ácidos grasos de la carne de vaquillonas con distinta pastura y tiempo de suplementación," Revista Argentina de Producción Animal, vol. 25, supplement 1, pp. 347-348, 2005.

[96] J. J. Grigera Naón, A. Schor, M. E. Cossu, V. Schindler de Avila, and F. Panella, "The effects of feeding by-products of soybeanharvest on the lipid composition and quality of beef," in Proceedings of the 49th International Congress of Meat Science and Technology, pp. 133-134, 2003. 

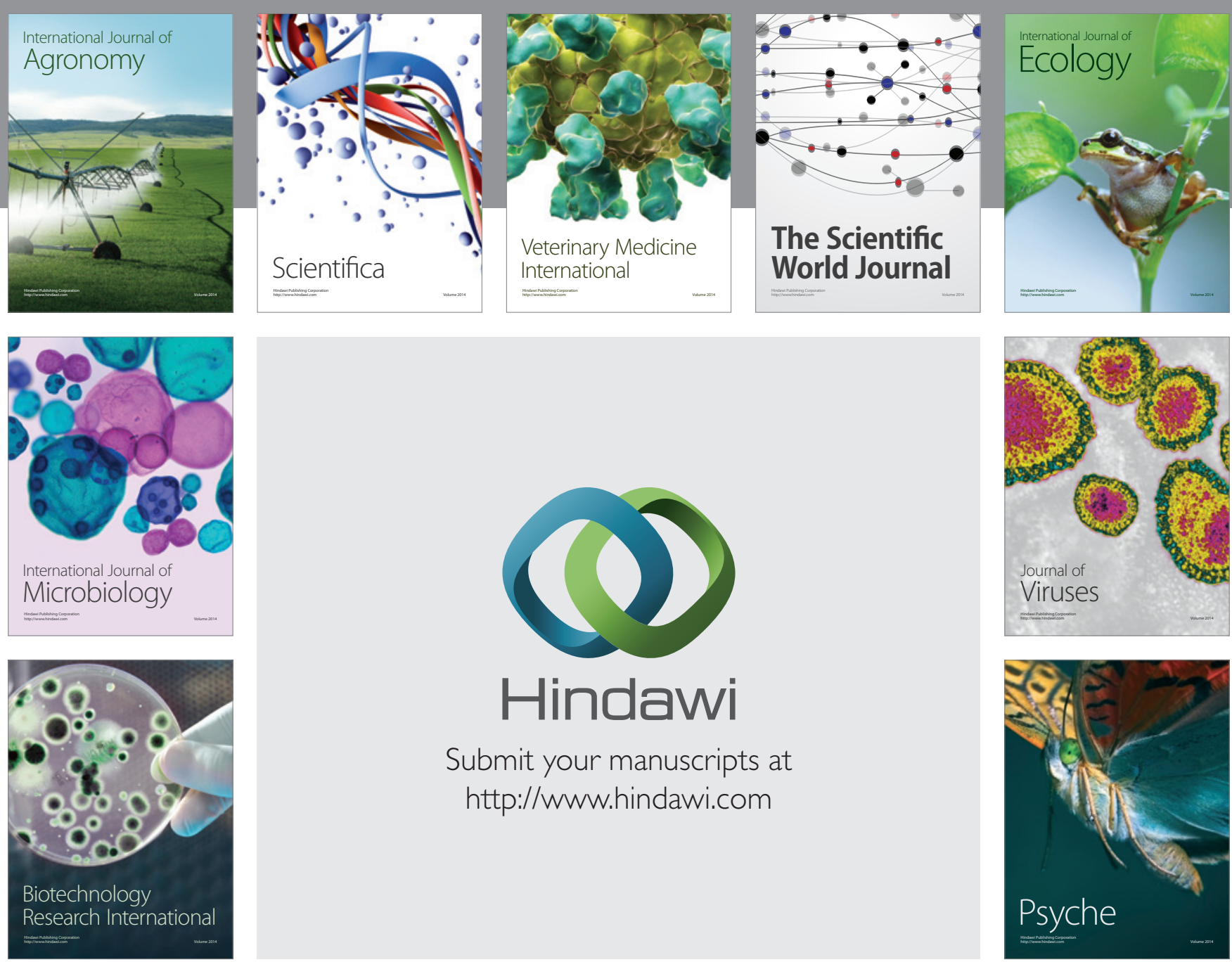

Submit your manuscripts at

http://www.hindawi.com
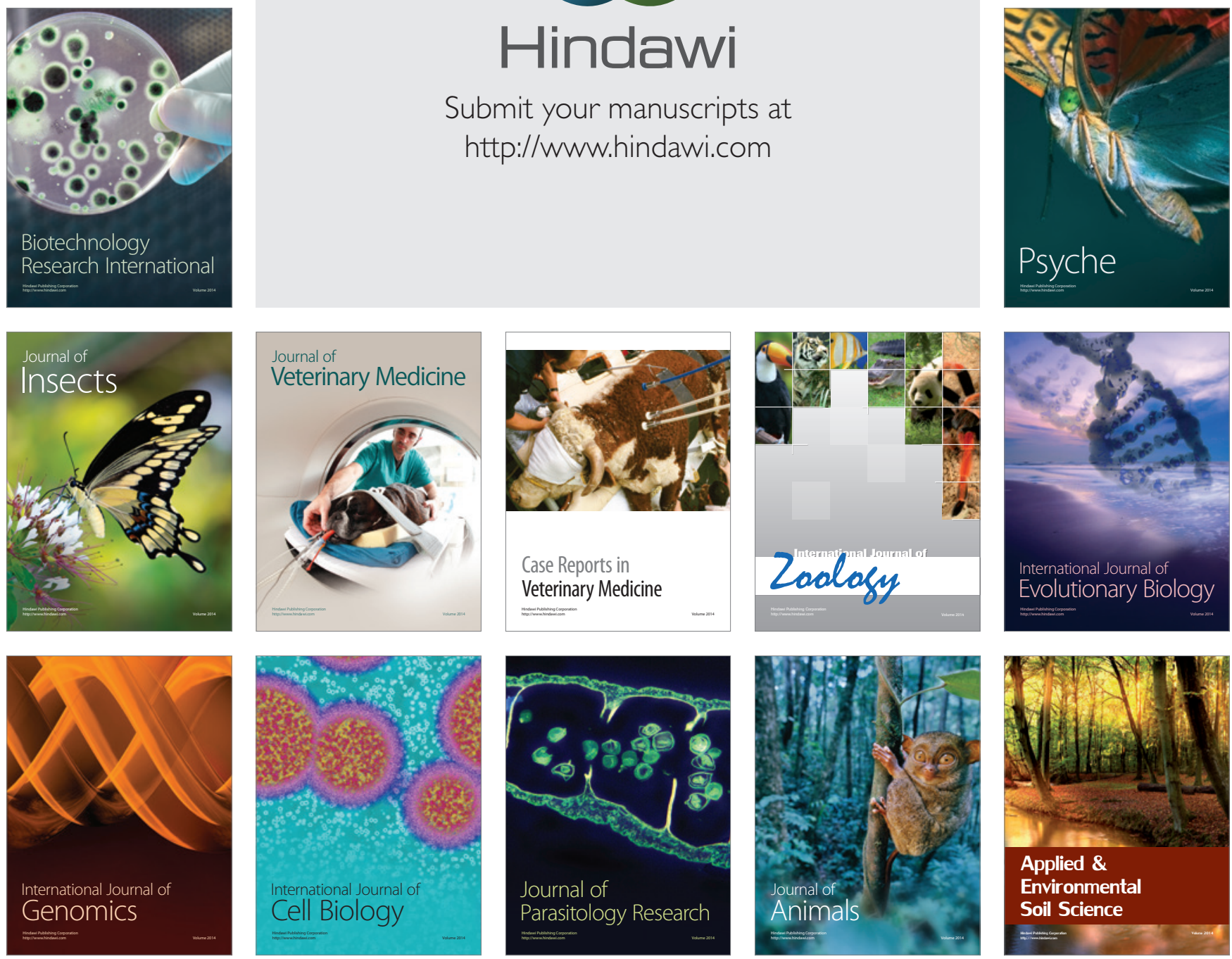